\title{
Determinants of Urban Housing Choice in Debre Berhan Town, North Shewa, Amhara Region, Ethiopia
}

\author{
By: Abebaw Hailu (MA) \\ Adviser: Mitiku Ayele (PhD) \\ Department of economics, Hawassa University, Hawassa, Ethiopia
}

\begin{abstract}
In developing countries, in the midst of important factors influencing urban housing choice, demographic, socioeconomic and institutional factors are the most critical. This study aims to investigate the determinants of housing choice in Debre Berhan town, Amhara Regional State, Ethiopia. Qualitative and quantitative data were used. Both primary and secondary data were used to carry out the study. A multistage sampling procedure was used and a total of 395 household heads was selected by a simple random sampling method from three home ownership alternatives of four Kebeles. Ordinary least square estimation technique was used to estimate the hedonic price of the house and multinomial logit model was used to estimate the determinants of housing choice in the study area. The result of the study indicated that age of household head, sex of the household head, educational level, the price of the housing, years of residence, income of the head and access to credit were determinants of urban housing choice in the study area. While, near amenities, floor material, age of the house and the numbers of the bedroom were significantly affected housing price in Debre Berhan town. The study recommends that government and stakeholders should support households to construct and purchase house.
\end{abstract}

Keywords: Housing Choice; Hedonic price and Multinomial Logit

DOI: $10.7176 / \mathrm{JESD} / 12-19-03$

Publication date:October $31^{\text {st }} 2021$

\section{INTRODUCTION}

Housing is basic human needs, which have evolved from simple shelters to modern housing units. It has great importance to households in both developed and developing economies. Furthermore, it is the largest fixed capital investment and acts as a focus of economic activity, a symbol of achievement, social acceptance and an element of urban growth (Malpezzi, 2012). In many developing countries around 40\% (two third) urban residents are living in rented housing units. According to Malpezzi I (2014), majority of countries have some form of price control on some or all of their rental housing stock. Housing choice means having the ability to pick from alternatives, even if the options are imperfect solutions. There are different socio-economic and demographic factors which affect household housing choices, such as demographic changes, income level, the availability and location of housing units are some of the factors which prevail all over the world (Wildish,2015).

In Ethiopia there are 15,103,134 housing units among that, 12,206,116 units are found in the rural areas and the 2,897,018 units are found in the towns of the country. In urban parts of Ethiopia, $39 \%$ of the owner-occupied housing units and about $40 \%$ of the urban housing units are rented from private households. The average number of households per housing unit is 1.044 and the average number of rooms per housing is 1.8 units (CSA, 2014). Abnet et al (2017) indicated that, the major modality of housing tenure classified in to informal and informal urban housing provision; formal urban housing includes private rental arrangement, which is prevalent in most cities and owner occupancy (owner contracted and purchased) was the second and the third major tenure arrangements.

Muthoka (2015) and Anthony 2006), in Nairobi, Kenya were conducted on household demand for housing. Whereas, Housing provision and challenges of urban residents and assessment of the housing provision challenge for urban residents in Ethiopia (Kiros, 2009 and Muleta, 2014). However, most of the study was focused on factors affecting the real estate market and provision and challenges of urban housing demand. This study was focused on the determinants of urban housing choice by using two stage least squares estimation as input to the main model, particularly to estimate the hedonic price of housing and multinomial logit models to estimate the determinants urban housing choice. Given the major research and knowledge gap, this study intends to examine determinants of urban housing choice in Debre Berhan town, North Shewa, Amhara Region.

\section{OVER VIEW OF THE LITERATURE}

Housing refers to houses or buildings collectively, accommodation of people, planning or provision of accommodation by an authority, and related meanings (Wright, 1983). In Africa, in general and Sub-Saharan African countries in particular, the rapid increase in urban populations, urbanization, the persistently poor financial situation of the urban residents, bad governance and material resources available are the causes of increasing urban housing demand. Ethiopia is one of the poorly developed countries which are characterized by low per capita income, higher population growth rate, rapid urbanization, import-dependent, poor investment in housing because of lack of finance and low supply of serviced residential plot (UN-Habitat, 2010). According to Hood (1999), 
conducted on the determinants of home ownership in park place, used the logit model and OLS estimation technique. This study points out that family size and parental home ownership, proved to be a significant and positive effect on the household home ownership. Niedomysl (2008), conducted on residential preference in Swedes used cross-sectional data and OLS estimation technique applied. The study point out that sex, age, and the number of children produce significant effects on residential preference, while socioeconomic variables do not produce significant effects on residential preference.

Bujang,Hasmah A., Norhaslina J. (2010) conducted on the housing market and affordability in Malaysian. This study points out that, demographic factors such as marital status, number of households, age distribution, educational level, and household income of different respondents might have influenced the housing market and have resulted in different levels of affordability. In addition, peoples' preference was more focused on the double and single level of building houses. Spalkoval and Jiri (2014) conducted on housing tenure choice and housing expenditures in the Czech Republic. The paper investigates potential tenure choice determinants using probit regression model based on the sample data. The results of the analysis showed that tenure choice is affected by household income, marital status of the household head and household size. In addition to the logical influence of household income, tenure choice decisions are significantly influenced by household size and residence in Prague, particularly in the rented housing sector. Opaluwa and Aribigbola P. (2015), conducted on the factors affecting the choice of residential units in Lokoja, Kogi State, Nigeria was used cross-sectional data and multinomial logistic regression model. It found that household size, distance to health and medical facilities and distance to place of work affected the choice of the rooming house.

Sila (2015) was conducted on Household Demand for Housing in Kenya. The study used the Integrated Household Budget Survey 2005/2006. this study was used a multinomial logit model to estimate Housing demand for housing and Two Stage Least Square (2SLS) to took price as endogenous. The study found that land size, the location of the house, number of the bedroom, wall material and access to toilets are the major determinants of the hedonic price of the house. Regarding the determinants of housing choice, people will change from rented tenures to purchase only due to an increase in household size and age of the household head. Own-constructed tenure, a key and positive factor is household size and age of household head. Kiros (2016) was conducted on Factors Affecting the Real Estate Market: the case of Addis Ababa City. The study was used cross-sectional data and presented using basic descriptive statistical tools. The study found that the slow and insufficient supply of land, currently the shortage and increased prices of housing construction materials is another factor affecting the market. Tsion (2016), conducted the study on the assessment of affordability and living condition of condominium housing in Addis Ababa city, Ethiopia used cross-sectional data and mixing quantitative which is collected and gathered from the survey interpreted by using descriptive statistical tools and qualitative methods which means the collected data were organized and analyze thematically or narration by making summaries of the respondent's views. The finding water supply, open space, the size of the rooms and domestic noise are considered as the main challenges of living in condominium housing. Véronique, (2017), conducted on residential choice in Lille, northern France used econometrics with discrete choice models. Found that, residential choices are influenced by age, income, and size of the household, as well as by the rent-to-income ratio. An increase in any of these variables decreases the probability of choices of all the alternatives other than the most often chosen alternative. Moreover, the distance to work systematically influences the housing choice for single-parent families and two-earner households.

\subsection{Conceptual Framework of the Study}

The household is assumed to derive utility from consuming housing unit and non-housing goods. The objective of any consumer is to maximize his/her utility subject to a budget constraint. The marginal utility of a household may relate to some different characteristics of houses, which have a bearing on household s' satisfaction. For instances size, color, wall material, age of house, housing facilities and roofing. The presence of these favorable qualities improves utility, without necessarily increasing the number of units purchased and at the same time attracts higher rents (Sila, 2015). 


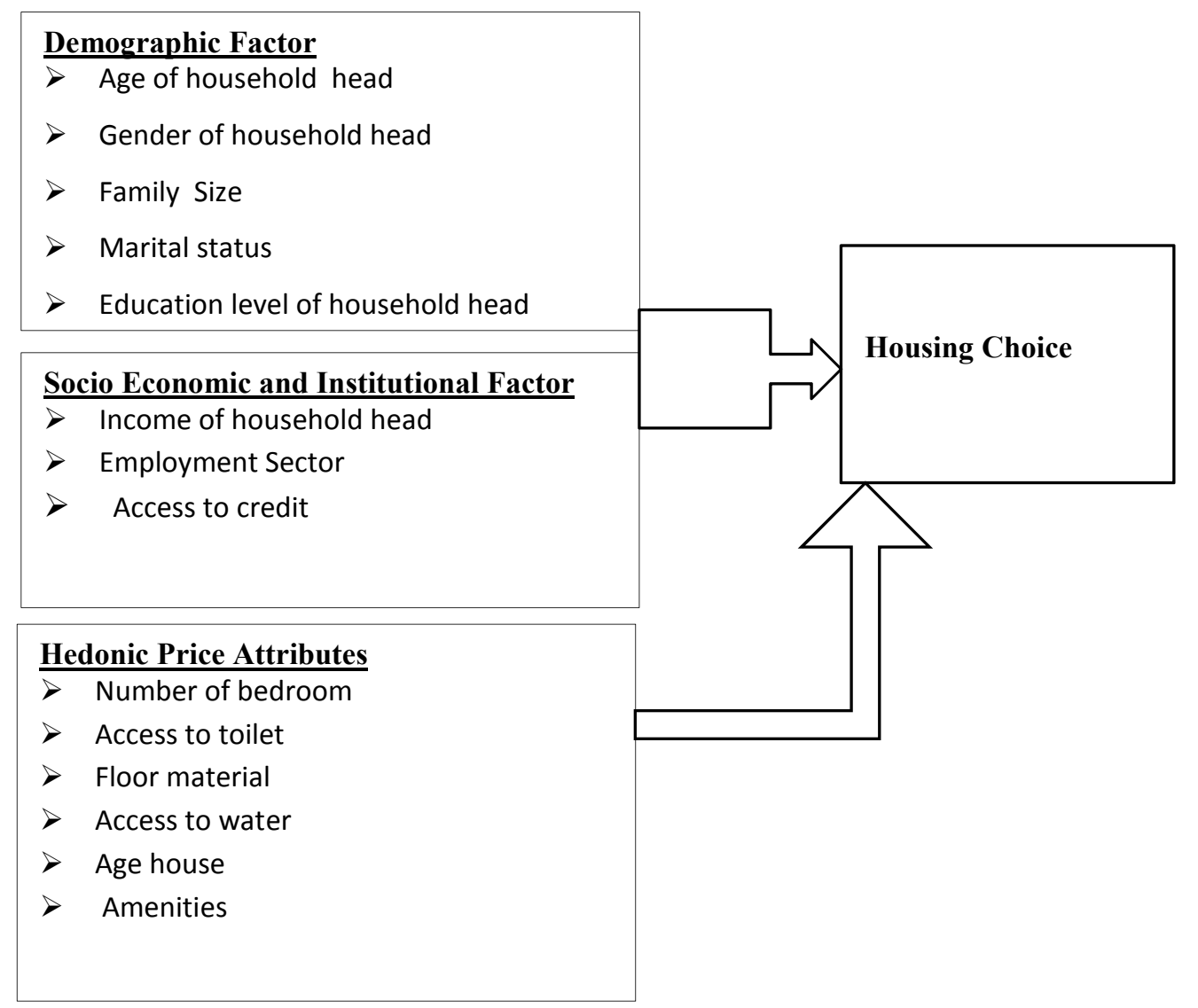

Figure 1: Socioeconomic and demographic factors of housing choice Source: Adopted from Li Shi (2000) and with modification from literature

\subsection{Empirical Framework}

In the first stage, it is necessary to discuss some approaches used in the measurement of housing prices in the analysis. Price is endogenous in the theory of demand, so here before we are going to multinomial logit model the first step is test the endogenity of the price of house, which allows the price to be endogenously determined and then used as an input in the main model and used hedonic price to estimate the determinants of housing price. After test the price of housing was endogenous. Therefore, it implied to the study use hedonic regression model the characteristics of a housing unit to develop a price index for house. Based on this there are locational, structural and environmental attributes, which affect the price of the house, incorporated those attributes in this model is mandatory to avoid endogenity problem. Even if the study used the hedonic pricing model it is difficult to predict three different types of housing price. To estimate the price of the house the study used engineering price for an own constructed house, while the price of the house what the consumer was actually paid since the payment was undertaken to the last day the survey date for purchases house and used rental price for the rented house. Some scholars ( such as Sila, 2015 and Hood,1999) were put hedonic pricing model in the form of the log-linear form, which is in the form of log-linearized, but this study was used in the form of linear regression to see the linear relationship between dependent variable and independent variable .

$P H=\alpha_{0}+\alpha_{1}$ (number of bed rooms) $+\alpha_{2}$ (access to toilet dummy) $+\alpha_{3}$ (floor material) $+\alpha_{4}$ (amenities dummy) $+\alpha_{5}$ (age of house) $+a_{6}$ (access to water dummy) $+v------e q(1)$

Where $\alpha_{0}$ is the intercept, $\alpha_{1}$ and $\alpha_{5}$ are a continuous parameter, $\alpha_{3}, \alpha_{2}, \alpha_{4}$ and $\alpha_{6}$ dummy parameters. Hedonic price attributed to house age, which is measured (in years), number of bedrooms measured in number, access to toilets, access to water and near to amenities around the residential areas (such as public facilities) influencing the price of housing.

In the second stage, I model demand as a choice variable across three common types of housing in Debre Berhan town. The construction of condominium and kebele of house are stagnant in the study area. Form policy perspective government subordinate the household to live in his/her own house by constructed, otherwise rented house and purchased house otherwise in rented house. This study assumes that the urban housing choice can be used for three (3) mutually exclusive housing units. At a particular time, the household could be only living in the privately rented house, only living own constructed house, and only in the purchased house. This gives rise to a polychotomous choice framework. Hence the probability of home ownerships $(\mathrm{j}=0$ private rented house only; $\mathrm{j}=1$ 
own constructed house only; $\mathrm{j}=2$ purchased only) is given by the following MNL model. The multinomial probability model assumes that the possible distinct states are exhaustive in that they cover all possibilities. In the multinomial case, the rented house is considered the base level and all the logit are made relative to the base category. When category $\mathrm{k}$ is taken as a base category, and let be the multinomial probability of an observation falling in the jth category, then the MLM specified as follows;

$$
\operatorname{Pr}(Y i=j)=\frac{\exp (X i \beta j)}{1+\sum_{k=1}^{N} \exp (X i \beta k)} \text {, For } \mathrm{j}=1,2 \ldots(\mathrm{k}-1) \text { and } \mathrm{i}=1,2,3 \ldots \mathrm{n}--------e q(2)
$$

Where, $\mathrm{Yi}$ is housing choice, $\beta i$ is the vector of parameters and $\mathrm{Xi}$ is a vector of all explanatory variables those are age of household head, sex of household head, marital status head, family size, educational level of the household head, employment sector, income of household head, access to credit, years of residence and price of housing and $\varepsilon \mathrm{i}$ is the disturbance term of the equation. The interpretation of the MNL model is relative to the reference or base category group is difficult, even if this study used rented only as a base category. The coefficients need to be adjusted to be marginal effects in the case of the logit model.

\section{METHODOLOGY}

\subsection{Study Area Profile}

Debre Berhan or Birhan, formerly spelled Debra-Birhan or Bernam, is a city and woreda in central Ethiopia. Located in the North Shewa Zone in the Amhara Region, about 130 kilometers northeast of Addis Ababa on the paved highway to Dessie, the town has a latitude and longitude of $9^{\circ} 41^{\prime} \mathrm{N} 39^{\circ} 32^{\prime} \mathrm{E}$ and an elevation of 2,840 meters. It was an early capital of Ethiopia and afterward, with Ankober and Angolalla, was one of the capitals of the kingdom of Shewa. Today, it is the administrative center of the North Shewa Zone of the Amhara Region. Debre Birhan town has nine kebele with a total population of 65,231 whom 31,668 are men and 33,563 women and 20650 was the total number of households (Chisholm, Hugh, ed, 1911).

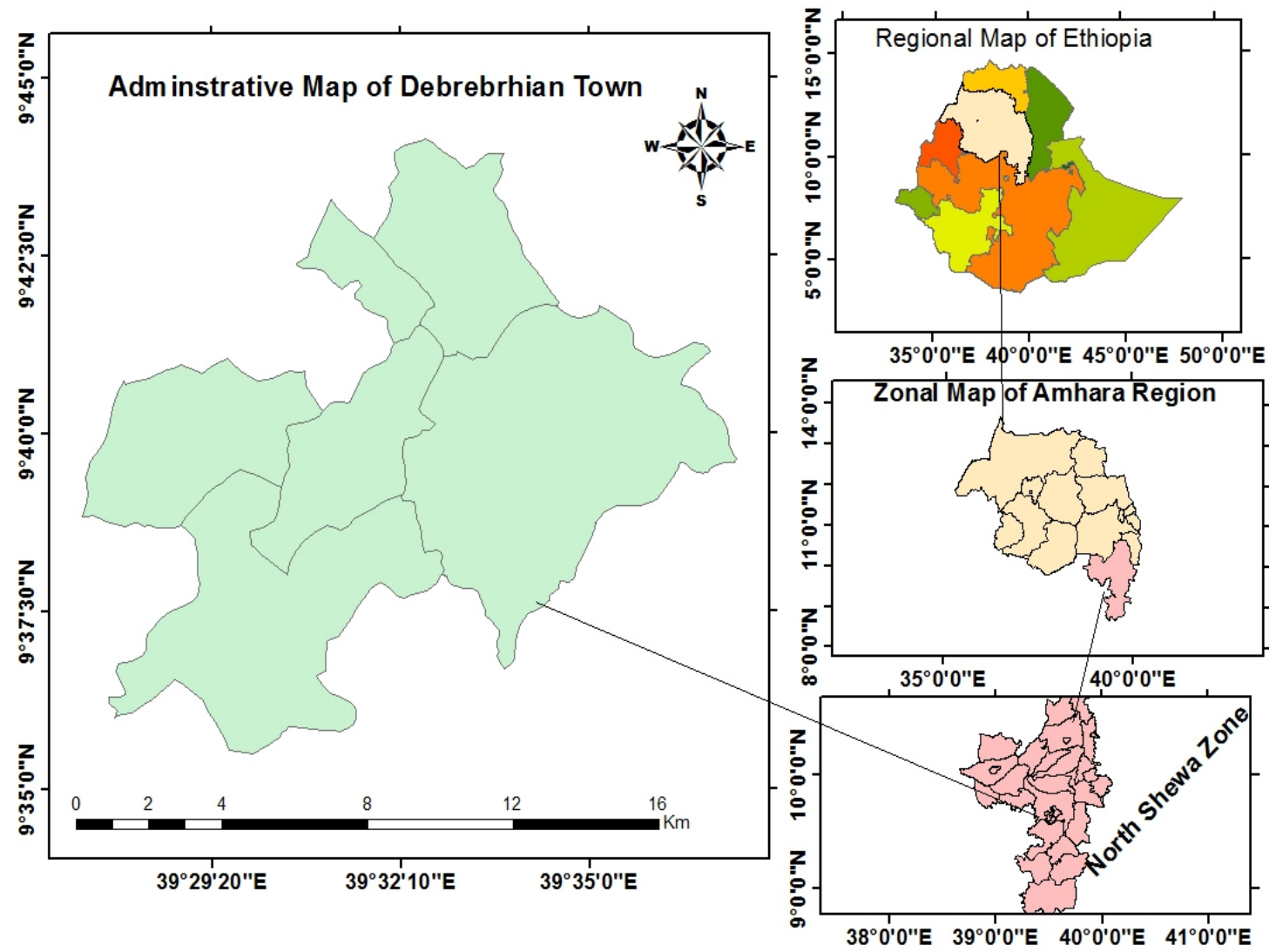

Figure 2 : Geographical Location of Debre Birhan Town of North Shewa

\subsection{Data and Discussion}

The study used both quantitative and qualitative research approach. In analyzing the quantitative data presented with the help of tables, percentages, frequency and figures. The qualitative data are also analyzed by using the narrative mechanism. Primary and secondary data were collected for this study. Primary data were collected through structured questionnaires. The questionnaires were design as close-ended type. The questionnaires were 
pre-test to check its clarity and understandability by local people (respondents) and to get quality data, and the researcher supervises the data collection using methods like on the interviewing key questions and observation. For this particular study, a multi-stage sampling procedure was implemented. Initially the simple random sampling technique was used to take the sampled kebele from total (nine) kebeles. However, the numbers of household, who are resided in those kebeles, are not homogenous. Therefore, to make homogenous stratification is needed to ensure desired number of households in the town and to improve the precision of the sample by reducing sampling error. As a result stratification undertaken based on home ownership (private rented, own constructed and purchased house). After stratification, proportional sampling was used to take the sample size from each stratum. In total 395 sample sizes. The data is collected from different sources have been edited, interpret and analysis by using descriptive analysis and econometric models; ordinary least square used to estimate the determinants of housing price and multinomial logit model to identify the determinants of urban housing choice after the completion of the data collection.

Table 1: Description of the model of variable, its measurement and Expected sign

\begin{tabular}{|c|c|c|c|}
\hline \multirow{3}{*}{$\begin{array}{l}\text { Variable Name and } \\
\text { symbol } \\
\text { Housing Choice }\end{array}$} & Description and measurement of variables & \multicolumn{2}{|c|}{ Expected sign } \\
\hline & It is a categorical variable (priv & Dependent & variable \\
\hline & constructed $=1$, and purchased $=2$ ). & Construct & Purchase \\
\hline $\begin{array}{l}\text { Age Household } \\
\text { head(AGEHD) }\end{array}$ & $\begin{array}{l}\text { Defined as the number of years from the date of birth to the } \\
\text { day of the survey interview date in the full year. This is } \\
\text { measured to in years. }\end{array}$ & + ve & $+\mathrm{ve}$ \\
\hline $\begin{array}{l}\text { Sex of household } \\
\text { head(SEXHD) }\end{array}$ & It is a dummy variable which can be (male $=1$ and 0 otherwise). & $+\mathrm{ve}$ & $+\mathrm{ve}$ \\
\hline $\begin{array}{l}\text { Marital } \\
\text { status(MARS) }\end{array}$ & $\begin{array}{l}\text { It is a categorical variable } 0 " \text { if single,"1" widowed,"2"" } \\
\text { divorced.and"3" married }\end{array}$ & $+\mathrm{ve}$ & $+\mathrm{ve}$ \\
\hline $\begin{array}{l}\text { Family } \\
\text { size(FMSIZE) }\end{array}$ & $\begin{array}{l}\text { One or more persons occupying a housing unit and have the } \\
\text { same eating arrangement. Measurement in number }\end{array}$ & $+\mathrm{ve}$ & $+\mathrm{ve}$ \\
\hline $\begin{array}{l}\text { Educational level of } \\
\text { household } \\
\text { head(EDUCHD) }\end{array}$ & $\begin{array}{l}\text { It is a continuous variable, in which households are literate or } \\
\text { illiterate. Measured in years of formal schooling. }\end{array}$ & $+\mathrm{ve}$ & $+\mathrm{ve}$ \\
\hline $\begin{array}{l}\text { Employment sector } \\
\text { of head (EMPSHD) }\end{array}$ & $\begin{array}{l}\text { It is a dummy variable which is categorized ' } 0 \text { ' public sector, } \\
\text { ' } 1 \text { ' private sector. }\end{array}$ & $+\mathrm{ve}$ & $+\mathrm{ve}$ \\
\hline $\begin{array}{l}\text { Income of household } \\
\text { head (INCHD) }\end{array}$ & $\begin{array}{l}\text { Permanent disposable income of a household measured in } \\
\text { Ethiopian Birr (ETB) }\end{array}$ & $+\mathrm{ve}$ & $+\mathrm{ve}$ \\
\hline $\begin{array}{l}\text { Access } \\
\text { credit }(\mathbf{A c C r})\end{array}$ & $\begin{array}{l}\text { It is a dummy variable which can be an individual } 1 \text { if access } \\
\text { to credit, } 0 \text { otherwise }\end{array}$ & $+\mathrm{ve}$ & $+\mathrm{ve}$ \\
\hline $\begin{array}{l}\text { Years of } \\
\text { residence(YRED) }\end{array}$ & $\begin{array}{l}\text { It is a continuous variable, which means an individual how } \\
\text { many years stayed in the study area, which can be measured in } \\
\text { year. }\end{array}$ & $+\mathrm{ve}$ & $-\mathrm{ve}$ \\
\hline Hedonic price (HP) & $\begin{array}{l}\text { It is a continuous variable, which means the quantity of } \\
\text { payment given by one party to another in return for goods or } \\
\text { services. Measurement in Ethiopian Birr (ETB) }\end{array}$ & $+\mathrm{ve}$ & $+\mathrm{ve}$ \\
\hline
\end{tabular}

\section{RESULTS AND DISCUSSIONS}

\subsection{Descriptive statistics}

This research interprets and analysis the findings gathered from primary and secondary sources. The results of the study focused on the determinants of urban housing choice. In this study, 424 questionnaires were prepared and distributed to the respondent out of these 395 (93\%) questionnaires were properly completed and returned on time. The finding has been presented and analyzed under the following themes: demographic and socioeconomic characteristics of the respondents, to examine the determinants of urban housing choice.

Table 2: Summary statistics on the hedonic price of a house

\begin{tabular}{lccccc} 
Variable & Obs & Mean & Std.Dev. & Min & Max \\
\hline Price of house (PH) & 395 & 196695.8 & 275751 & 300 & 1500000 \\
Nobedroom (NoBEDR) & 395 & 1.721519 & .9253441 & 1 & 5 \\
Age of house (AGEH) & 395 & 14.44304 & 76523 & 2 & 40
\end{tabular}


Table 2; show that the mean and the standard deviation price of housing were 196695.8 Birr (ETB) and 275751 respectively. The data indicate that there is an extreme difference between min price 300 and max price 1500000 Birr (ETB). The mean number of bedrooms was 1.721519 and .9253441 standard deviation. Furthermore, the min number of bedrooms is 1 and max 5 bedrooms. The mean age of the house is 14.44304 with standard deviation 8.476523, the minimum and maximum age of the house is 2 and 40 respectively.

Table 3: Percentage distribution on choice variable

\begin{tabular}{lll}
\hline Housing Choice & Freq. & Percent \\
\hline Rented house & 209 & 52.91 \\
constructed house & 108 & 27.34 \\
Purchased house & 78 & 19.75 \\
Total & 395 & 100.00 \\
\hline
\end{tabular}

Computed from own data survey result, 2018

Table 3 shows that urban household, housing ownership is 209 (52.91\%) households were living in the privately rented house, $108(27.34 \%)$ were living in own constructed house and 78 (19.75) households were living in the purchased house.

\subsection{Econometric Analysis}

In econometric analysis, the study applies a method of analysis of ordinary least square estimation parameters of linear regression, while maximum likelihood estimation technique for the purpose of estimating the multinomial logit functions. For the purpose of effective estimation of the model several of the pre and post-estimation diagnostics tests were conducted. For instance, the study performs tests like endogenity test, link test, normality test and heteroskedasticity test only for linear regression, multicollinearity test for both model, independence of irrelevant alternative test (IIA), Likelihood ratio test for independence of the variables, combination test among the alternatives of the model and goodness of fit test were seriously conducted only for multinomial logit (MNL) model.

4.2.1. Hedonic Regression

Table 4: Hedonic price coefficient

\begin{tabular}{|c|c|c|c|c|}
\hline $\mathrm{PH}$ & & Coef. & Std. & $\mathrm{p}>[\mathrm{t}]$ \\
\hline Number of bedrooms(NoBEDR) & & $183,000 * * *$ & 15,490 & 0.000 \\
\hline Access to toilet (Ac toilet) & & 67.55 & 18,876 & 0.997 \\
\hline Floor material (FM) & & $51,729 * * *$ & 17,389 & 0.003 \\
\hline Access to water( AW) & & $130,784^{*}$ & 66,905 & 0.051 \\
\hline Age of house (AH) & & $-2,719 * * *$ & 1,001 & 0.007 \\
\hline Amenities (AMN) & & $88,304 * * *$ & 18,744 & 0.000 \\
\hline Mean dependent var & 196695.772 & SD dependent var & & 275750.974 \\
\hline R-squared & 0.549 & Number of obs & & 395.000 \\
\hline F-test & 56.824 & Prob $>$ F & & 0.000 \\
\hline Akaike crit. (AIC) & 10715.701 & Bayesian crit. (BIC) & & 10743.553 \\
\hline
\end{tabular}

Source: own survey, 2018

Note: $* * *$ and $* * *$ are level of significance at 10,5 and $1 \%$ respectively

Tables 4 reveals that the $\mathrm{R}^{2}$ for the model was 0.549 this means $54.5 \%$ of the variance of the response variable price of a house is explained by regression model and the rest is due to an error. It may be necessary to note again that robust errors are reported because they reduce the effect of outliers in significance tests. The location (near to amenities) rather than far apart from the amenities and number of bedrooms are both positive and significant at the $5 \%$ and access to water significant at the $10 \%$ level of significance. On average the value of the price of housing was higher for nearer to amenities than far from amenities by 88,304 Birr (ETB), holding all other variables constant. Concerning, the number of bedrooms as a number of bedrooms increased by one room, then the price of the housing increased by 183,000 Birr (ETB), while other things remain constant. On average the value of the variable price of housing was higher for access to water than not to access to water by 130,784 Birr (ETB), ceteris paribus. As floor material of house become complexity, then the price of the housing was increased by 51,729 Birr (ETB), holding all other variables constant. For an increase in the age of the house of one year, there is expected to decrease the price of housing by 2,719 Birr (ETB), holding all other variables constant. The coefficients conform to expectations and theory and suggest that an improvement in these hedonic characteristics of housing units tend to increase prices in a linear manner except the age of the house. This result is positively consistent with recent studies conducted in Kenya, which indicated that location and number of bedrooms were significant variable in explaining hedonic pricing (Sila, 2015). 
4.2.2. Multinomial Logit Estimation Results

Table 5: Multinomial logit coefficients and marginal effect rented house is a base level

\begin{tabular}{|c|c|c|c|c|c|c|}
\hline \multirow[t]{2}{*}{$\mathrm{Yi}$} & \multicolumn{2}{|c|}{ Constructed house } & \multicolumn{4}{|c|}{ Purchased house } \\
\hline & Coef. & Std. & $\operatorname{Mfx}(\mathrm{dy} / \mathrm{dx})$ & Coef. & Std. & $\operatorname{Mfx}(\mathrm{dy} / \mathrm{dx})$ \\
\hline Head age (AGEHD) & $0.0974 *$ & 0.0533 & .0042299 & $0.234 * * *$ & 0.0648 & .002298 \\
\hline Head sex (SEXHD) & $10.95^{* * *}$ & 1.717 & .2668742 & $9.202 * * *$ & 1.861 & .041541 \\
\hline $\begin{array}{l}\text { Head marital status } \\
\text { (MARS) }\end{array}$ & 0.590 & 0.459 & .0259704 & 0.664 & 0.530 & .006366 \\
\hline Family size (FMSIZE) & 0.297 & 0.377 & .0131678 & 0.156 & 0.398 & .001422 \\
\hline Head educational (EDUC) & $0.226^{* *}$ & 0.109 & .0099412 & $0.238^{* *}$ & 0.112 & .002276 \\
\hline $\begin{array}{l}\text { Employment } \\
\text { sector(EMPS) }\end{array}$ & $1.268^{*}$ & 0.653 & .0451711 & $2.238 * * *$ & 0.799 & .016153 \\
\hline Head income (INC) & 0.000219 & 0.000203 & $9.43 e-06$ & $0.000710^{* * *}$ & 0.00022 & $7.00 \mathrm{e}-06$ \\
\hline Access to credit( $\mathrm{AcCr})$ & $3.565^{* *}$ & 1.751 & .3882483 & $3.568^{* *}$ & 1.801 & .084075 \\
\hline Years of residence (YRED) & $0.0661 * * *$ & 0.0229 & .002952 & -0.0129 & 0.0225 & -.000160 \\
\hline Hedonic price(HP) & $\begin{array}{l}1.48 \mathrm{e}- \\
05^{* * *}\end{array}$ & $\begin{array}{l}2.99 \mathrm{e}- \\
06)\end{array}$ & $6.52 \mathrm{e}-07$ & $1.34 \mathrm{e}-05^{* * *}$ & $\begin{array}{l}3.09 \mathrm{e}- \\
06\end{array}$ & $1.27 \mathrm{e}-07$ \\
\hline Mean dependent var & 0.668 & SD depen & ent var & 0.786 & & \\
\hline Pseudo r-squared & 0.723 & Number o & obs & 395.000 & & \\
\hline Chi-square & 1631.888 & Prob $>$ chi & & 0.000 & & \\
\hline Akaike crit. (AIC) & 265.021 & Bayesian & rit. (BIC) & 352.556 & & \\
\hline
\end{tabular}

Source: Computed from own data survey result, 2018

Note: $* * *$ and $* * *$ are level of significance at 10,5 and $1 \%$ respectively

Table 5 demonstrates that, the model converges after eleven iterations and has Log pseudo likelihood = 110.51046, Prob $>$ chi $2=0.0000$, Wald chi2 $(18)=1631.89$ and Pseudo R2 $=0.7235$. Pseudo R2 tells us our model as a whole fits significantly better than an empty model (i.e., a model with no predictors).

Age of household head (AGEHD)

The parameters of the age of households have positive and significant at $10 \%$ for own construct houses and $5 \%$ for purchased house. As a household head gets older and older, then households were more likely to construct, own house and to purchase the house rather than renting, holding all other variables constant. The marginal effect indicates that as the age of the household head increase by one a year, then the probability of constructing own house and purchased increases by $0.423 \%$ and $0.23 \%$, respectively, relative to renting a house, holding all other variables constant. The implication may be due to that older household head may own more income and have more wealth (asset and income) which helps them to construct and purchase housing. Those households spent more years in the workforce and their incomes have most likely risen to their level of experience. This result is consistent with recent studies conducted in Kenya, which indicated that age of household head was significant variable in explaining housing choice (Sila, 2015).

Sex household head (SEXHD)

Sex of household head is both positive and significant at the $5 \%$ level of significance. Male headed households are more likely to construct and to purchase houses as compared to female headed households. The marginal effect of the variable shows that when the household head is male, then probability of constructing and purchase has house increased by $26.68 \%$ and $4.15 \%$ with relative to rented respectively, all other things being equal. This implies that, males often have higher incomes which are more certain because males never leave the workforce for such expected events as childbearing and rearing. As a result, males have the opportunity to gain more experience in the workforce (by working continuously over their work life) and even more with a particular company. This result is consistent with recent studies conducted in the swedes, which indicated that sex of household head was significant variable in explaining housing choice (Niedomysl, 2008).

\section{Educational level of household head (EDUCHD)}

The educational level of household head is also positive and significant at the $5 \%$ level of significance. The more educated household's heads are more likely to construct and purchased house relative to rented house. The marginal effect indicates that as household's head educational level increase by one year, the probability of constructing and purchased house increase by $0.99 \%$ and $0.23 \%$ relative to rented house respectively, holding all other variables constant. This tells as household heads with a high level of educational attainment will often have a good job with a generous salary. This result is consistent with recent studies conducted in the Malaysia which indicated that education of the head is significant variable in explaining housing choice (Bujang et al, 2010).

\section{Employment sector of household head (EMPSHD)}

Employment sector of household head is positive and significant at the 5\% level of significance. This point out that, households who were employed in the private sector more likely to construct, own house and purchasing a 
house, than counterparts, holding all other variables constant. This implies that households are working in the private sector (for instance private business and NGOs) than in public sector employed, because they earn flexible(depend on the economic situation). The marginal effect indicates that as households who are employed in the private sector, then the probability of constructing and purchased house increase by $4.51 \%$ and $1.61 \%$ relative to rented house respectively, ceteris paribus. This implies that households are working in the private sector (for instance private business and NGOs) than in public sector employed, because they earn flexible(depend on the economic situation). This result is consistent with recent studies conducted in the Hawassa city which indicated that employment sector is a significant variable in explaining housing choice (Regassa, B., 2015).

\section{Access to credit (AcCr)}

Access to credit was positive and significant at 5\% significance level. As household heads were access to credit, then more likely to construct and purchased house relative to rented houses. The marginal effect indicates that as household heads access to credit then, the probability of constructing own house and purchased has increased by $38.82 \%$ and $8.41 \%$ relative to rented house respectively, holding all other variables constant. This result is consistent with recent studies conducted in Malaysia which indicated that access to credit, was significant variable in explaining housing choice Abdul-Lateef and Tan, (2017).

\section{Income of household head (INCHD)}

The relationship between the Income of household head and housing choice is positive and significant for purchased house at the 5\% level of significance. Households with higher incomes are more likely to purchase house relative to rented houses. The marginal effect indicates that, as the income of a household increase by one ETB the probability of purchasing house increase by $(7.00 \mathrm{e}-06)=0.0007 \%$ relative to a rented house, while other things remain constant. This implies higher incomes means greater demand for properties, as the general purchasing power of household's increases and they choose to spend a greater proportion of their consumption on living, other things remain constant. This result is oppositely consistent with recent studies conducted in Kenya, which indicated that income was significant variable in explaining housing choice (Sila, 2015).

\section{Years of residence (YRED)}

A year of residence was positive and significant for constructed house at 5\% significance level. As households are staying for long years, then households are more likely to construct, own house with relative to a rented house, holding all other variables constant. The marginal effect indicates that, as household head years of residence has increased by one year, then, the probability of constructing own house increase by $0.295 \%$ with relative to a rented house, ceteris paribus. This implies, as households are staying for long years, then households fulfill some of the criteria's to obtain land in the form of lease to construct, own house. This result is consistent with recent studies conducted in the Czech Republic which indicated that years of residence was significant variable in explaining housing choice (Spalkoval and Jiri Spalik, 2014).

\section{Hedonic price of housing (HP)}

Lastly, the general hedonic price of housing is both positive and significant at the $5 \%$ level of significance. As the higher general hedonic price of house households are more likely to construct, own house and to purchase house over-rented house, holding all other variables constant. The marginal effect indicates that, as the general hedonic price of a house is increased by one Birr (ETB) the probability of both constructing own house and purchased has increased by $(6.52 \mathrm{e}-07)=0.0000652 \%$ and $(1.27 \mathrm{e}-07)=0.0000127 \%$ with relative to rent, while other things remain constant. This implies that even if the price of house increases consumers are willing to construct and purchase house, related to the income of household heads and fulfilling all services related to housing is increasing household pleasure results rise up willing to pay, lead to rising house prices. This result is consistent with recent studies conducted in Kenya, which indicated that general hedonic price was significant variable in explaining housing choice (Sila, 2015).

\section{Conclusion and Policy Implication}

The issue of urban housing choice is a major concern for developing countries, particularly in Ethiopia. A wide spread of arguments continues as to what it contributes and how to tackle so as to see better tomorrow. There are different alternatives of houses in the study area, thus are rented, own constructed and purchased. From descriptive statistics, most of the households were living in the private rented house in Debre Birhan town. This study found that, access to water, the age of the house, near to amenities, floor material of the house and numbers of bedrooms have a significant effect on the price of the house in which to determine it. The major determinants of urban housing choice, which prohibited from changing rented to construct and purchase are age of head, sex of head, income of household head, access to credit, employment sector, educational level and general housing price of the housing and years of residence.

The government and stakeholders should increase the income of the households, provide housing finance in the form of loan to be returned in the long run, given different training to create job opportunity instead of waiting for employment in the public sector, avoid long lived restriction and set stabile housing price to encourage households to purchase housing and construct own house. 


\subsection{Areas for Further Research}

The study was limited in Debre Berhan town, North Shewa, Amhara region. There were also restrictions on variables were some that affect housing choice were omitted land size, land price, wall material and income of family. Consequently, I recommend that future studies on housing choice should include those variables, which is not considered in this study.

\section{ACKNOWLEDGMENT}

I am thanks to GOD for everything he has done to me. I am deeply grateful to my major advisor Dr. Mitiku Ayele for his professional suggestions, guidance and overall assistance starting from the research proposal up to thesis write up. My special thanks to my co-advisor Mr. Mussie Dereje for his valuable comments and significant advises during proposal preparation, data collection and thesis write up. It is my pleasure to extend my thanks to the Debre Berhan University with whose permission to join the MA. Program and with whose sponsorships for research and accommodation this document would have been materialized. Finally, I would like to express my sincere appreciation to my family, relatives and real friends for their encouragement and inspiration, which made the study a success.

\section{References}

AbdulLateef Olanrewaju Tan Chai Woon . (2015). an exploration of determinants of affordable housing choice. International Journal of Housing Markets and Analysis, Vol 10 (Issue 5), pp.703-723,. doi: https://doi.org/10.1108/IJHMA-11-2016 0074.

Abnet G B,. Yonas A, Dawit B, Imam H, Tsion L. (2017). Housing in Ethiopia”. Social Inclusion and Energy Management for Informal Urban Settlements .

Anthony, O. (2006). determinants of housing choice.

Aqubamicheal, K. (2009). Factors Affecting the Real Estate Market:the case of Addis Ababa City, Unpublished M.Sc.

Bujang,Hasmah Abu Zarin, Norhaslina Jumadi. (2010). the relationship between demographic factors and housing affordability Malaysian (Vol. Volume ). England: The MIT Press.

Chisholm,Hugh . (1911). Abyssinia province and town. (11thed ed.). The Netherlands the Netherlands: Cambridge University Press. Retrieved from Encyclopedia Britannica

CSA. (2014). National Statistics Report. Addis Ababa, Ethiopia.

Flambard, V. (2010). Demand for housing choices in the north of France: a discrete Approach", . Journal of European Real Estate Research, , Vol. 10 (Issue: 3), pp.346-365. doi:doi.org/10.1108/JERER-11-2016-0038 Permanent link to this document

Getachew, T. (2016). Assessment of Affordability and Living Condition of Condominium Housing in Addis Ababa. (Unpublished masters' thesis).

Hood , Jaclyn K. (1999). The Determinants of Home Ownership: An Application of Human Capital Investment Theory to the Home Ownership Decision". Retrieved from http://digitalcommons.iwu.edu/econ honproj/71.

Malpezzi, S. (2012). Factors Affecting Motives for Housing Demand in Tipple and K.G. Willis, eds., Housing the Poor in the Developing World: Methods of Analysis, Case Studies and Policies. pp. 208-233 .

Malpezzi, S. (2014). "Discounted cash flow analysis: present value analysis of housing programmes and policies", in: A.G. Tipple and K.G. Willis, eds., Housing the Poor in the Developing World: Methods of Analysis, Case Studies and Policies. pp. 208-233.

Muthoka, S. (2015). Household Choice for Housing. Retrieved from http://mpra.ub.uni-muenchen.de/65469

Muthoka, S. (2015). Household Choice for Housing in Kenya University. Retrieved from http://mpra.ub.unimuenchen.de/65469/

Niedomysl, T. (2008). Residential preferences for interregional migration in Sweden: demographic, socioeconomic, and geographical determinants. Environment and Planning, . p.1109-1131. .

Opaluwa and Aribigbola P. . (2015). Factors Affecting the Choice of Residential Housing. International Journal of Innovative Science, Engineering \& Technology, volume 2(Issue 10 ).

Regassa, B. Regassa, N. (2015). Housing and Poverty in Southern Ethiopia: Examine in Affordability of Condominium Houses in Hawassa City, Economics and Sociology,. Vol. 8, pp. 155-169. doi:10.14254/2071789X.2015/8-3/12

Shi, L. (2000). Housing preference of residents in Stellenbosch, (unpublished maters thesis).

Spalkoval, Jiri Spalik. (2014). Housing Tenure Choice and Housing Expenditures in the Czech Republic. Review of European Studies;. Published by Canadian Center of Science and Education, Vol. 6(ISSN 1918-7173 EISSN 1918-7181. ).

UN-Habitat. (2010). The Ethiopia Case of Condominium Housing: The Integrated Housing using the 1991 Residential Finance Survey,. Journal of Real Estate Finance and Economics, 235- 255.

Wildish, B. (2015). Housing choice and preference: a review of the literature. Auckland. 
Wordofa, M. (2014). Assessment of Housing Provision Challenges on Urban Residents: The Case of Bekoji Town, Arsi Zone, Oromia Regional State, Ethiopia. Unpublished M.Sc.

Wright, Gwendolyn. (1983). Building the Dream: A Social History of Housing in America. MIT press. 